\title{
CAMINHA E OS INDÍGENAS
}

Rodrigo de Medeiros Silva ${ }^{1}(28 / 08 / 18)$

Não se preocupam com as vergonhas, Relatou este nobre escrivão Porta voz desta cultura medonha

De mil conquistas e exploração.

Distante da realidade tratada

Julga por sua lente enviesada,

Aí se trouxe mundo civilizado,

Da boa família e do bom cristão,

Discurso bastante sofisticado,

Para guerras, matanças e traição

Distante da realidade tratada

Julga por sua lente enviesada

Falam de um projeto nacional

1 Advogado Popular e poeta éMestre em Direitos Humanos pela UniRitter, Porto Alegre/ RS (2019); graduou-se em Direito pela Universidade de Fortaleza-UNIFOR, Fortaleza/CE (2003); e especialista em Direito Civil e Processual Civil, pelo Instituto de Desenvolvimento Cultural - IDC, em Porto Alegre-RS (2016). Integra os grupos de estudos da UniRItter Direitos Humanos e Violência e Direitos Humanos e Literatura. Fez cursos de extensão em Direitos Humanos pela Unicap, em Recife-PE (2004/2005), e em Direito Civil e Processo Civil pela UnB, em Brasília-SF (2006). É membro e fundador do Instituto de Pesquisa Direitos e Movimentos Sociais- IPDMS e conselheiro da Seção Sul do Instituto. Foi Consultor da UNESCO para o Marco Regulatório das Organizações da Sociedade Civil, junto à Secretaria de Governo da Presidência da República (2015/2016). Ainda foi assessor no Relatório da Carcinicultura da Câmara dos Deputados (2004/2005) e do relator da CPMI da Terra (2005/2006). Participa da Rede Nacional de Advogadas e Advogados Populares-RENAP, Fórum Justiça, Articulação Justiça e Direitos HumanosJusDH e do Coletivo de Advogados Ambientalistas do Rio Grande do Sul. 
Que só Ihes cabe ter aceitação,

Roubam terras, acham tudo normal,

Direitos?! Isto é texto em vão.

Distante da realidade tratada

Julga por sua lente enviesada,

Agora Caminha encastelada,

Longe dos Kaigang, da demanda dada 